\title{
Strength properties of fresh and weathered rocks subjected to wetting-
}

\section{drying cycles}

\author{
Ivan Gratchev ${ }^{1)}$, Savani Vidana Pathiranagei ${ }^{2}$ and Dong Hyun Kim ${ }^{3)}$ \\ 1) Senior Lecturer, Griffith School of Engineering, Griffith University, Southport, Australia, \\ E-mail: ivangratchev@gmail.com \\ 2) PhD candidate, Griffith School of Engineering, Griffith University, Southport, Australia \\ 3) Formerly PhD candidate, Griffith School of Engineering, Griffith University, Southport,
} Australia

Abstract. Unlike previous research on soft and clay-bearing rocks, this study seeks to investigate the effect of wetting and drying (W-D) cycles on the engineering properties of two hard rocks. A series of W-D cycles were applied to fresh specimens of greywacke and basalt, and their strength, slake durability and density were progressively assessed as the number of cycles increased. It was found that unlike the basalt, the strength of greywacke rapidly decreased with increasing W-D cycles while the rock density and slake durability index remained almost the same. Analysis of the crack propagation in both rocks revealed that, compared to soft and clay-bearing material, the process of strength degradation in hard rocks was rather different, with a more pronounced effect of crack development. In addition, comparisons with the data obtained for the same type of rocks yet naturally weathered was performed to establish similarities between the properties of laboratory-deteriorated and naturally weathered rocks. The obtained results are expected to provide more practical values for such laboratory studies where the rate of rock deterioration is relatively high (several weeks) in comparison to what is commonly observed in the field (several years).

Key words: wetting and drying cycles; weathering; point load test; slake durability index. 


\section{Introduction}

Natural rocks are one of the oldest building materials that are still in great demand at the present time. In the Southeast Queensland area (Australia), rock supplies mostly come from meta-greywacke deposits of the Neranleigh-Fernvale Beds as well as basalt lavas of the Lamington Volcanics formation (Willmott 1992). When subjected to weathering, the properties of these rocks gradually deteriorate, making them less suitable for construction purposes. There have been several studies in the past decades (Hall and Hall 1996; Topal and Doyuran 1998; Gokceoglu et al. 2000; Topal and Sozmen 2003; Mutluturk et al. 2004; Akin and Ozsan 2011; Ozbek 2014; Zhang et al. 2015; Zhou et al. 2017) to estimate the durability of rocks in the laboratory through a series of wetting-drying (W-D) cycles. However, most of the aforementioned studies were performed on relatively weak and/or clay-bearing rocks, in which the effect of W-D cycles was mostly seen in the water-clay interaction and "the weakening of the intergranular bonds" (Gokceoglu et al. 2000). It is not yet clear what effect W-D cycles can have on engineering properties of relatively hard rocks.

Despite the apparent progress in this area, it still remains unclear whether such laboratory studies can be utilized to accurately estimate the durability and strength degradation of rocks in the field because no comparisons between the properties of "laboratory-deteriorated" and "naturally weathered" rocks have yet been provided. The available literature indicates that the rate of rock deterioration in the laboratory is rather different from what is commonly observed in the field. For example, Tating et al. (2013) reported that the time to change sandstone from fresh to a slightly weathered state under field conditions may vary from 5 to 17 years, while most of the laboratory studies continued for only a few weeks. In addition, W-D cycles typically cause only physical changes to the rock while no sufficient time in such experiments is allowed for chemical changes to occur (White and Brantley, 2003). 
To shed light on these issues, this study seeks to a) investigate the process of strength degradation which can occur in two hard rocks subjected to W-D cycles; and b) establish similarities/differences between the properties of laboratory-deteriorated and naturally weathered rocks, which will provide more practical values to laboratory data. This paper presents and discusses the obtained results.

\section{Materials and method}

Borehole samples (diameter $50 \mathrm{~mm}$ ) of greywacke and basalt collected from two construction sites were provided for this research by local geotechnical companies. As the rock core was collected at different depths, it was possible to obtain fresh rocks at deeper depths as well as weathered core samples at relatively shallow depths. Visual examination of the samples (Fig. 1) was performed using the ISRM (1981) guidelines (Table 1) to determine the degree of weathering. The porosity test was performed on fresh and weathered rock specimens, according to AS 4133.2.1.2-2005 (2005).

The greywacke collected from the Pimpama area (Queensland, Australia) was part of metasediments of the Neranleigh-Fernvale Beds formation (Holcombe 1977; Kim et al. 2013; 2015). Visual examination of the samples revealed the presence of quartz veins as shown in

Fig. 1a. Fresh core specimens had a density of $2.66 \mathrm{~g} / \mathrm{cm}^{3}$ and porosity of about $2.5 \%$. The mineral composition of fresh and weathered greywacke (Fig. 2a) included medium-grained quartz, feldspars, chlorite, illite and kaolinite.

The basalt collected from the northern part of New South Wales was part of the Tertiary Lamington formation. The mineral composition (Fig. 2b) included plagioclase, olivine, pyroxene and anlcime. Visual observations indicated that the fresh basalt was of very high 
strength with no visible signs of weathering (Fig. 1b). The weathered rocks were much weaker, having undergone different stages of weathering (Fig. 1c). The weathering degree of all tested specimens is given in Table 2 .

To prepare rock samples for W-D experiments, the fresh greywacke and basalt were cut into cylinders of $50 \mathrm{~mm}$ high. The W-D procedure was performed following the ASTM D5313-04 (2004) test standard. Each sample was dried in an oven set to $105^{\circ} \mathrm{C}$ and its mass was recorded. The rock samples were then placed in a container filled with distilled water (the water level was $2 \mathrm{~cm}$ above the top surface), and let stand in water for 24 hours. The samples were next oven-dried at a temperature of $100^{\circ} \mathrm{C}$ for 24 hours before being placed in water again. The mass of sample was recorded after the saturation and dry stages in each cycle. Typical results showing changes in the rock mass during the W-D procedure are given in Fig. 3a for basalt and Fig. $3 b$ for greywacke.

After a certain number of W-D cycles, two samples were selected for point load (PL) tests to determine the strength of rocks. PL tests were performed following Australian Standard AS 4133.4.1-2007 (2007) to obtain the point load strength index $\left(\mathrm{I}_{\mathrm{s}(50))}\right)$. The average of two test results was calculated and used in analysis. To determine the rock durability, a series of slake durability (SD) tests were performed. SD tests were conducted in accordance with Australian Standard AS 4133.3.4 (2005) on the same rock samples that were previously tested in the point load apparatus. The slake durability index obtained after the second cycle $\left(\mathrm{I}_{\mathrm{d} 2}\right)$ as recommend by the relevant standard was used in this analysis. Summary of all test results obtained for both rocks subjected to W-D cycles is given in Table 3.

\section{Results and discussion}




\subsection{Crack development during W-D cycles}

Visual observations were made after each cycle to study the effect of the $\mathrm{W}$-D process on the rock structure and crack formation. It was found that the greywacke samples had the tendency to develop cracks due to changes in the moisture and temperature. As shown in Fig. 4, the cracks typically formed along the quartz veins while only minor discolouring was observed along the crack surface. The cracks progressively extended (Fig. 4b) and widened (Fig. 4c) as the number of W-D cycles increased. A few minor cracks also appeared (Fig. 4b) during the W-D process. These rapidly developed cracks were found to be the main reason for strength degradation of rocks.

W-D cycles had also some effect on the development of surface cracks in the basalt specimens, however this process was not as rapid as the one that was observed for the greywacke. To better understand the mechanism of crack development, a digital microscope was employed to measure the crack width after each cycle. Images taken after the first and last W-D cycles for two basalt specimens (B8 and B12) are given in Fig. 5 as an example, while changes in the crack width with increasing W-D cycles are summarized in Fig. 6. It is evident from Figs. 5 and 6 that the width of the crack increased by about 35\% (B12) and 40\% (B8) as a result of wetting and drying.

It is noted that for both greywacke and basalt, no significant changes in the mass of tested specimens (Fig. 3) were observed throughout the whole W-D procedure, which resulted in only minor changes in rock density and porosity (Table 3). Interestingly, Topal and Sozmen (2003), Akin and Ozsan (2011) reported similar results for tuff and travertine showing that the density of rock remained almost constant in spite of an increased number of W-D cycles. 


\subsection{Point load and slake durability test results}

Unlike the rock density, the W-D cycles had a more pronounced effect on the rock strength, especially for the greywacke specimens. The data from PL tests (Fig. 7a) indicate that as the number of W-D cycles increased, the point load strength index $\left(\mathrm{I}_{\mathrm{s} 50}\right)$ of greywacke significantly decreased. For example, in the case of fresh greywacke, $\mathrm{I}_{\mathrm{s}(50)}$ was as high as $8.1 \mathrm{MPa}$, then decreased to $5.0 \mathrm{MPa}$ after $3 \mathrm{~W}$-D cycles, and finally became as low as $1.3 \mathrm{MPa}$ after the $18^{\text {th }}$ cycle. Such a drastic change in the rock strength was associated with the crack development along the quartz veins. Strength reduction was also observed for the basalt (Fig. 7b); however, it took significantly longer to decrease the rock strength from $9.1 \mathrm{MPa}$ (fresh rocks) to $2.9 \mathrm{MPa}$ (after the $40^{\text {th }}$ cycle).

Results of slake durability tests on the greywacke (Fig. 7c) indicate that the slake durability index $\left(I_{d 2}\right)$ remained as high as $98.9 \%$ after 18 cycles despite the fact that the overall strength of the greywacke specimens significantly dropped. Gratchev and Kim (2016) noted that $\mathrm{I}_{\mathrm{d} 2}$ can serve as an indicator of the degree of weathering, and a value of $\mathrm{I}_{\mathrm{d} 2}>98 \%$ would typically be associated with fresh rocks of high strength. However, the data obtained for the "laboratorydeteriorated" greywacke indicate some contradiction to this trend as the greywacke specimens with very high values of $\mathrm{I}_{\mathrm{d} 2}(>98 \%)$ unexpectedly produced very low strength values. Visual observations during testing revealed that the rock specimens failed because of the well-defined cracks, which were developed along the quartz veins (Fig. 4) during W-D cycles. Other than these cracks, no significant changes of the rock structure were observed. Moreover, the rock pieces tested in the slake durability experiments were still of high strength with only minor discoloration along the cracks. Similarly, very high values of $I_{\mathrm{d} 2}$ were obtained for the basalt specimens, suggesting that no major changes to the specimen structure during W-D cycles occurred in this rock. 


\subsection{Test results on naturally weathered rocks}

A series of point load and slake durability tests were performed on naturally weathered greywacke and basalt and the obtained data are summarized in Table 2. Comparisons between the naturally weathered and laboratory-deteriorated rocks are given in Fig. 8 for greywacke (a) and basalt (b). It is evident from Fig. 8a that W-D cycles can indeed decrease the strength of rocks to a similar value which would be expected in the field. For example, a large decrease in the strength of fresh greywacke $\left(\mathrm{I}_{\mathrm{s}(50)}\right.$ was as low as $\left.1 \mathrm{MPa}\right)$, which was observed after several W-D cycles (Fig. 8a), could also occur in moderately (MW) and/or highly (HW) weathered rocks in the field (Table 2). However, the change in slake durability index $\left(\mathrm{I}_{\mathrm{d} 2}\right)$ observed for the greywacke under the laboratory conditions appears to be inconsistent with the data from the naturally weathered rocks. Figure $8 \mathrm{a}$ shows that $\mathrm{I}_{\mathrm{d} 2}$ of naturally weathered greywacke progressively decreased along with the rock strength; however, for the laboratory specimens subjected to W-D cycles, $\mathrm{I}_{\mathrm{d} 2}$ remained almost the same. In addition, the naturally weathered greywacke undergoes a relatively large decrease in rock density (about $8 \%$ ) as shown in Fig. 9a, while the same rock but only subjected to W-D cycles in the laboratory decreases its density by less than $2 \%$. Such inconsistences between the strength and density degradation of rocks caused by W-D cycles were also reported by Topal and Sozmen (2003). In that study, no significant change (less than $2 \%$ ) in the density of tuff was observed while the rock strength greatly decreased by $17.8 \%$.

Compared to the greywacke specimens, there seem to be better correlations between the properties of laboratory-deteriorated and naturally weathered basalt (Figs. 8b and 9b). For this rock, the process of crack development was less rapid and pronounced. In addition, basalt 
specimens remained high durability even when they were slightly or moderately weathered in nature.

\subsection{Discussion}

Previous studies have revealed a few processes that can occur in rock during W-D cycles:

1. For soft and clay-bearing rocks, swelling clay minerals can produce loading and unloading of tensile stresses caused by absorption and desorption of water (Gokceoglu et al. 2000; Ozbek 2014; Zhou et al. 2017). This can promote the growth and expansion of internal micro-cracks, resulting in increased porosity and lower strength of rock (Sarman et al. 1994; Zhang et al. 2015, Zhou et al. 2017).

2. The rock breakdown can occur due to physical factors such as the amount of fracturing and grain size (Felix 1983; Hall and Hall 1996; Bell et al. 1997). This process can affect a whole range of rocks including those that do not have a clay component. Moisture fluctuations can cause weathering as a result of the rock expanding during take up of water and its inability to return to the original dimensions upon losing moisture (Nepper-Christensen 1965).

3. Heating and cooling (as part of rock drying) can contribute to the breakage of rock as well; however, its effect seems to be less pronounced than that caused by wetting and drying. Bell et al. (1997), who heated mudstone to $105^{\circ} \mathrm{C}$ and then allowed it to cool at a room temperature, reported that this process had little effect on mudstone, except that some mudstone specimens developed minor hairline cracking. Khanlari and Abdilor (2015) arrived at similar conclusions when they subjected sandstone to 40 heat-cool cycles. The investigators noted that the heatcool treatment did not cause any significant change in the physical properties of the tested rock. 
The results of this study indicate that the aforementioned processes contributed to some extent to the breakdown of greywacke and basalt. For both types of rock, the crack development was more pronounced during the wetting stage, compared to the heating-cooling part. For greywacke, the formation and development of surface cracks along the quartz veins during the W-D testing appeared to be the dominant process. The small reduction in both density and porosity was mainly attributed to the weakening of bonds between grains while the presence of clay minerals that could absorb water resulted in additional stresses on the rock structure.

Although there are some similarities in strength reduction between the laboratorydeteriorated and naturally weathered greywacke, there is still some discrepancy in rock density and porosity. This difference can be related to the fact that W-D cycles cannot fully represent the natural weathering process, which is largely responsible for changes in rock properties (Tugrul 2004). Comparisons of the mineral composition between the laboratory-deteriorated (fresh) and highly weathered greywacke (Fig. 2a) reveal that in the weathered rock, the clay minerals have more pronounced peaks while the feldspar intensity has decreased. The available literature on weathered greywacke (Syers et al. 1970; Hodder and Hetherington 1991) suggests that during natural weathering, feldspar tends to transform to clay minerals, thus decreasing the rock density.

The data obtained for basalt gives a better agreement between the properties of laboratorydeteriorated and naturally weathered specimens (Figs. $8 \mathrm{~b}$ and $9 \mathrm{~b}$ ). The mineral composition of fresh and weathered rocks seems to be similar (Fig. 2b); however, the weathered specimen yields higher peaks of clay minerals. It is interesting that despite a relatively small decrease in density, the slightly weathered (SW) basalt specimens with no visible structural defects exhibited a relatively large decrease in strength. Similar findings were reported by Moon and Jayawardane (2004), who studied the properties of Karamu basalt from New Zealand. The investigators noted that the strength loss occurred at a slightly weathered stage, before the 
major macro-fracture development was obvious and before secondary mineral formation was apparent in the field. This phenomenon was attributed to chemical changes in basalt; in particular, the loss of alkaline earth elements at early stages of weathering.

\section{Conclusions}

In this work, the effect of wetting and drying (W-D) cycles on the engineering properties of two hard rocks (namely, greywacke and basalt) was investigated. To better understand the processes that occurred in rock during W-D cycles, the properties of laboratory-deteriorated rocks were compared with the properties of naturally weathered rocks. The following main conclusions can be drawn:

- W-D cycles can reduce the strength of fresh rocks (both greywacke and basalt) to a level which would be expected from slightly and moderately weathered rocks in the field. Results of this study suggest that a strength reduction of naturally weathered rocks can be estimated to some extent using data from W-D laboratory tests.

- The process of crack development along the quartz vein during W-D cycles seems to play a key role in a relatively rapid strength reduction of fresh greywacke specimens. The crack formation was promoted through the weakening of intergranular bonds caused by absorption and desorption of water.

- Some inconsistencies in the properties of the laboratory-deteriorated and naturally weathered greywacke were observed. A decrease in rock density caused by W-D cycles was significantly smaller than what was observed in the naturally weathered rocks. This discrepancy was attributed to the mineral composition where the weathered rock exhibited higher peaks for clay minerals. 


\section{Acknowledgments}

The authors would like to acknowledge Mrs Yun Zou and Rory Goodwin for their help with laboratory testing. This research was performed with the financial support of the Griffith University Postgraduate Research Scholarship (GUPRS) program.

\section{Conflict of interests}

On behalf of all authors, the corresponding author states that there is no conflict of interest.

\section{References}

ASTM D 5313 - 04 (2004) Standard AS Standard Test Method for Evaluation of Durability of Rock for Erosion Control Under Wetting and Drying Conditions

Australian Standard AS 4133.4.1-2007 (2007) Method 4.1: Rock strength testsDetermination of point load strength index

Australian Standard AS 4133.3.4-2005 (2005) Methods of testing rocks for engineering purposes. Method 3.4: Rock swelling and slake durability tests-Determination of the slake durability index of rock samples

Australian Standard AS 4133.2.1.2-2005 (2005) Methods of testing rocks for engineering purposes. Method 2.1.2: Rock porosity and density tests- Determination of rock porosity and dry density-Saturation and buoyancy techniques 
Akin M, Ozsan A (2011) Evaluation of the long-term durability of yellow travertine using accelerated weathering tests. Bulletin of Engineering Geology and the Environment 70: 101114

Bell FG, Entwisle DC, Culshaw MG (1997) A geotechnical survey of some British Coal Measures mudstones, with particular emphasis on durability. Engineering Geology 46 (2): $115-29$

Felix C (1983) Sandstone linear swelling due to isothermal water sorption. In LCP publications 1975-1995: Matériaux de construction. Pierre. Materials Science and Restoration, International Conference, 305-310

Gokceoglu C, Ulusay R, Sonmez H (2000) Factors affecting the durability of selected weak and clay-bearing rocks from Turkey, with particular emphasis on the influence of the number of drying and wetting cycles. Engineering Geology 57: 215-237

Gratchev I, Kim DH (2016) On the reliability of the strength retention ratio for estimating the strength of weathered rocks. Engineering Geology 201: 1-5

Hall K, Hall A (1996) Weathering by wetting and drying: some experimental results. Earth Surface Processes and Landforms 21(4): 365-376

Hodder AP, Hetherington JR (1991) A quantitative study of the weathering of greywacke. Engineering Geology 31 (3-4): 353-68

Holcombe RJ (1977) Structure and tectonic history of the Brisbane metamorphics in the Brisbane area. Journal of Geological Society of Australia 24 (7-8): 475-489

ISRM (1981) Basic geotechnical description of rock masses. International Journal of Rock Mechanics Mining Sciences and Geomechanics Abstracts 18: 85-110 
Khanlari G, Abdilor Y (2015) Influence of wet-dry, freeze-thaw, and heat-cool cycles on the physical and mechanical properties of Upper Red sandstones in central Iran. Bulletin of engineering geology and the environment 74 (4): 1287-1300

Kim DH, Gratchev I, Balasubramaniam AS (2013) Determination of joint roughness coefficient (JRC) for slope stability analysis: a case study from the Gold Coast area, Australia. Landslides 10 (5): 657-664

Kim DH, Gratchev I, Balasubramaniam AS (2015) Back analysis of a natural jointed rock slope based on the photogrammetry method. Landslides 12 (1):147-54

Moon V, Jayawardane J (2004) Geomechanical and geochemical changes during early stages of weathering of Karamu Basalt, New Zealand. Engineering geology 74 (1-2): 57-72

Mutluturk M, Altindag R, Turk G (2004) A decay function model for the integrity loss of rock when subjected to recurrent cycles of freezing-thawing and heating-cooling. International Journal of Rock Mechanics and Mining Sciences 41: 237-244

Nepper-Christensen P (1965) Shrinkage and swelling of rocks due to moisture movements. Medd dansk geol 15: 548-55

Ozbek A (2014) Investigation of the effects of wetting-drying and freezing-thawing cycles on some physical and mechanical properties of selected ignimbrites. Bulletin of Engineering Geology and the Environment 73: 595-609

Sarman R, Shakoor A, Palmer DF (1994) A multiple regression approach to predict swelling in mudrocks. Bulletin of the Association of Engineering Geologists 31(1): 107-21

Syers JK, Williams JD, Walker TW, Chapman SL (1970) Mineralogy and forms of inorganic phosphorus in a greywacke soi-rock weathering sequence. Soil Science 110 (2): 100-106 
Tating F, Hack R, Jetten V (2013) Engineering aspects and time effects of rapid deterioration of sandstone in the tropical environment of Sabah, Malaysia. Engineering Geology 159, 2030

Topal T, Doyuran V (1998) Analyses of deterioration of the Cappadocian tuff, Turkey. Environmental Geology 34 (1): 5-20

Topal T, Sozmen B (2003) Deterioration mechanisms of tuffs in Midas monument. Engineering Geology 68: $201-223$

Tugrul A (2004) The effect of weathering on pore geometry and compressive strength of selected rock types from Turkey. Engineering Geology 75: 215-227

White AF, Brantley SL (2003) The effect of time on the weathering of silicate minerals: why do weathering rates differ in the laboratory and field? Chemical Geology 202, 479- 506

Willmott WF (1992) Rocks and landscapes of the Gold Coast hinterland: geology and excursions in the Gold Coast and Albert and Beaudesert Shires. Geological Society of Australia

Zhang D, Chen A, Wang X, Liu G (2015) Quantitative determination of the effect of temperature on mudstone decay during wet-dry cycles: A case study of 'purple mudstone' from south-western China. Geomorphology 246: 1-6

Zhang BY, Zhang JH, Sun GL (2015) Deformation and shear strength of rockfill materials composed of soft siltstones subjected to stress, cyclical drying/wetting and temperature variations. Engineering Geology 190: 87-97

Zhou Z, Cai X, Chen L, Cao W, Zhao Y, Xiong C (2017). Influence of cyclic wetting and drying on physical and dynamic properties of sandstone. Engineering Geology 220: 1-12 


\section{Figure captions.}

Figure 1. A view of fresh greywacke (a), fresh basalt (b) and weathered samples (c).

Figure 2. Mineral compositions of fresh and weathered rocks: a) greywacke; and b) basalt.

Figure 3. Changes in the rock mass during the W-D procedure: a) basalt, and b) greywacke.

Figure 4. Changes in the appearance of greywacke specimen after 1 cycle (a), 5 cycles (b), 12 cycles (c), and 15 cycles (d).

Figures 5. Crack development in basalt specimens: Specimen B8 after cycle 1 (a) and cycle 21 (b); Specimen B12 after cycle 1 (c) and cycle 40 (d).

Figure 6. Changes in the crack's width in basalt specimens B8 and B12.

Figure 7. Results of point load tests plotted as the number of W-D cycles against the point load index $\left(I_{s 50}\right)$ for greywacke (a), basalt $(b)$, and slake durability index $\left(I_{d 2}\right)$ for both rocks (c).

Figure 8 . Test results obtained for the laboratory deteriorated and naturally weathered greywacke (a) and basalt (b).

Figure 9. Changes in the rock density and strength obtained for the laboratory deteriorated and naturally weathered greywacke (a) and basalt (b). 
Table 1. Description of weathering degrees

\begin{tabular}{|l|l|}
\hline Term & $\begin{array}{l}\text { Description } \\
\text { (after ISRM, 1981) }\end{array}$ \\
\hline Fresh & $\begin{array}{l}\text { No visible sign of } \\
\text { weathering }\end{array}$ \\
\hline $\begin{array}{l}\text { Slightly } \\
\text { weathered } \\
\text { (SW) }\end{array}$ & $\begin{array}{l}\text { Rock may be discoloured } \\
\text { and may be somewhat } \\
\text { weaker than in its fresh } \\
\text { conditions }\end{array}$ \\
\hline $\begin{array}{l}\text { Moderately } \\
\text { weathered } \\
\text { (MW) }\end{array}$ & $\begin{array}{l}\text { Less than half of the rock } \\
\text { material is decomposed } \\
\text { and/or disintegrated to a } \\
\text { soil. }\end{array}$ \\
\hline $\begin{array}{l}\text { Highly } \\
\text { weathered } \\
\text { (HW) }\end{array}$ & $\begin{array}{l}\text { More than half of the } \\
\text { rock material is } \\
\text { decomposed and/or } \\
\text { disintegrated to a soil. }\end{array}$ \\
\hline
\end{tabular}


Table 2. Properties of naturally weathered rocks.

\begin{tabular}{|c|c|c|c|c|c|c|c|c|c|}
\hline $\begin{array}{c}\text { Weathering } \\
\text { degree }\end{array}$ & $\begin{array}{c}\text { Point } \\
\text { load } \\
\text { index, } \\
\text { MPa }\end{array}$ & $\begin{array}{c}\text { Slake } \\
\text { durability } \\
\text { index, } \%\end{array}$ & $\begin{array}{c}\text { Density, } \\
\mathrm{g} / \mathrm{cm}^{3}\end{array}$ & $\begin{array}{c}\text { Porosity, } \\
\%\end{array}$ & $\begin{array}{c}\text { Weathering } \\
\text { degree }\end{array}$ & $\begin{array}{c}\text { Point } \\
\text { load } \\
\text { index, } \\
\text { MPa }\end{array}$ & $\begin{array}{c}\text { Slake } \\
\text { durability } \\
\text { index, } \%\end{array}$ & $\begin{array}{c}\text { Density, } \\
\mathrm{g} / \mathrm{cm}^{3}\end{array}$ & $\begin{array}{c}\text { Porosity, } \\
\%\end{array}$ \\
\hline \multicolumn{6}{|c|}{ Greywacke } & & \multicolumn{5}{|c|}{ Basalt } \\
\hline F & 8.1 & 99.5 & 2.66 & 2.5 & F & 9.1 & 98.7 & 2.95 & 1.4 \\
\hline SW & 5.6 & 98.3 & 2.63 & 3.2 & SW & 5.1 & 98.2 & 2.91 & - \\
\hline SW & 3.9 & 97.2 & 2.61 & 3.3 & SW & 3.9 & 97.7 & 2.82 & 2.4 \\
\hline SW & 2.7 & 95.9 & 2.61 & 3.6 & MW & 2.6 & 97.3 & 2.74 & - \\
\hline MW & 2.3 & 96.7 & 2.58 & 5.2 & MW & 1.9 & 96.0 & 2.57 & 14.5 \\
\hline MW & 2.1 & 96.6 & 2.52 & 4.7 & MW & 1.6 & 95.6 & 2.51 & 18.1 \\
\hline MW & 1.6 & 95.0 & 2.50 & 4.8 & HW & 1.2 & 93.1 & 2.37 & 18.2 \\
\hline HW & 1.3 & 91.7 & 2.48 & - & HW & 1.0 & 93.2 & 2.33 & - \\
\hline HW & 1.4 & 90.5 & 2.45 & 18.1 & HW & 0.7 & 89.6 & 2.16 & 25.0 \\
\hline HW & 1.1 & 83.5 & 2.45 & 22.4 & HW & 0.9 & 87.2 & 2.15 & 26.3 \\
\hline & & & & & HW & 0.6 & 84.1 & 2.16 & 27.2 \\
\hline
\end{tabular}

Note: F - fresh, SW - slightly weathered, MW - moderately weathered, HW - highly weathered. 
Table 3. Data for fresh rocks subjected to recurrent wetting and drying cycles.

\begin{tabular}{|c|c|c|c|c|c|c|c|c|c|c|}
\hline $\begin{array}{c}\text { Cycle } \\
\text { No. }\end{array}$ & $\begin{array}{c}\text { Sample } \\
\text { No. }\end{array}$ & $\begin{array}{c}\text { Point } \\
\text { load } \\
\text { index, } \\
\text { MPa }\end{array}$ & $\begin{array}{c}\text { Slake } \\
\text { durability } \\
\text { index, } \%\end{array}$ & $\begin{array}{c}\text { Density, } \\
\mathrm{g} / \mathrm{cm}^{3}\end{array}$ & $\begin{array}{c}\text { Porosity, } \\
\%\end{array}$ & $\begin{array}{c}\text { Sample } \\
\text { No. }\end{array}$ & $\begin{array}{c}\text { Point } \\
\text { load } \\
\text { index, } \\
\text { MPa }\end{array}$ & $\begin{array}{c}\text { Slake } \\
\text { durability } \\
\text { index, } \%\end{array}$ & $\begin{array}{c}\text { Density, } \\
\mathrm{g} / \mathrm{cm}^{3}\end{array}$ & $\begin{array}{c}\text { Porosity, } \\
\%\end{array}$ \\
\cline { 2 - 13 } & \multicolumn{6}{|c|}{ Greywacke } & \multicolumn{5}{|c|}{ Basalt } & \\
\hline 0 & G1 & 8.1 & 99.5 & 2.66 & 2.5 & B1 & 9.1 & 99.4 & 2.96 & 1.4 \\
\hline 3 & G2 & 5.0 & 99.2 & 2.65 & - & B2 & 8.9 & 99.1 & 2.95 & 1.9 \\
\hline 6 & G3 & 2.9 & 99.2 & 2.64 & 3.1 & B3 & 8.7 & 99.2 & 2.95 & - \\
\hline 9 & G4 & 2.2 & 99.2 & 2.62 & - & B4 & 6.7 & 98.7 & 2.95 & - \\
\hline 12 & G5 & 1.2 & 98.9 & 2.64 & 3.3 & B5 & 7.2 & 98.7 & 2.95 & 2.1 \\
\hline 15 & G6 & 1.3 & 98.7 & 2.65 & - & B6 & 6.6 & 98.5 & 2.95 & - \\
\hline 18 & G7 & 1.3 & 98.9 & 2.63 & 3.7 & B7 & 5.4 & 98.4 & 2.95 & - \\
\hline 21 & & & & & & B8 & 6.1 & 98.3 & 2.94 & 2.3 \\
\hline 25 & & & & & & B9 & 5.3 & 98.1 & 2.91 & - \\
\hline 30 & & & & & & B10 & 4.2 & 98.0 & 2.89 & 3.5 \\
\hline 35 & & & & & & B11 & 3.9 & 97.8 & 2.88 & - \\
\hline 40 & & & & & & B12 & 2.9 & 97.6 & 2.85 & 3.2 \\
\hline
\end{tabular}




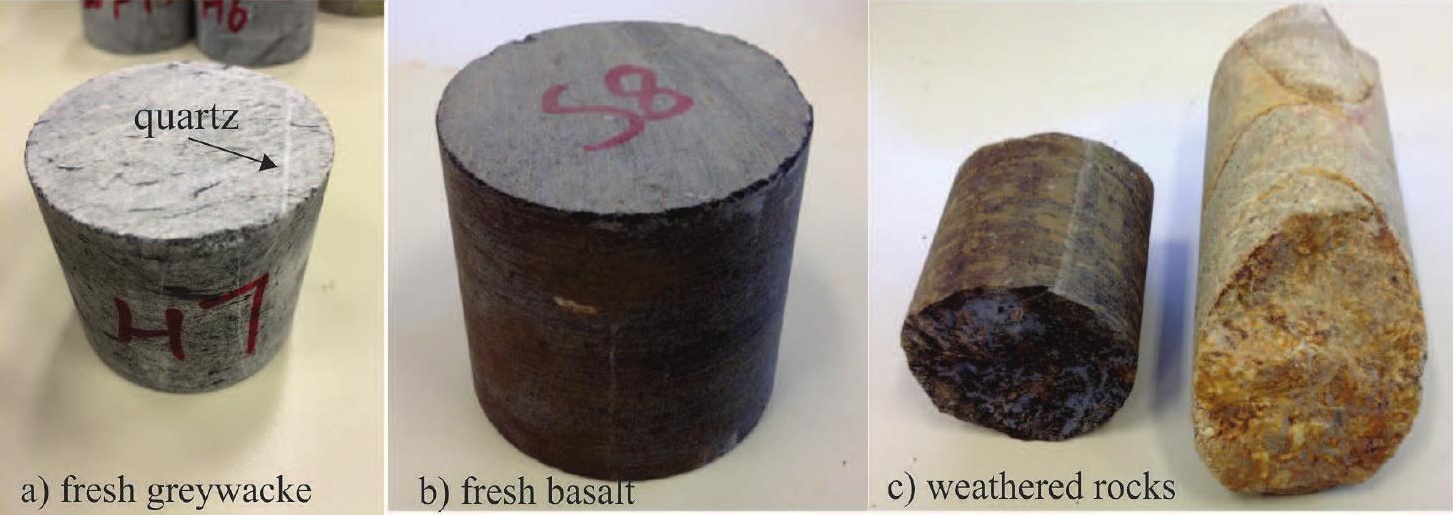



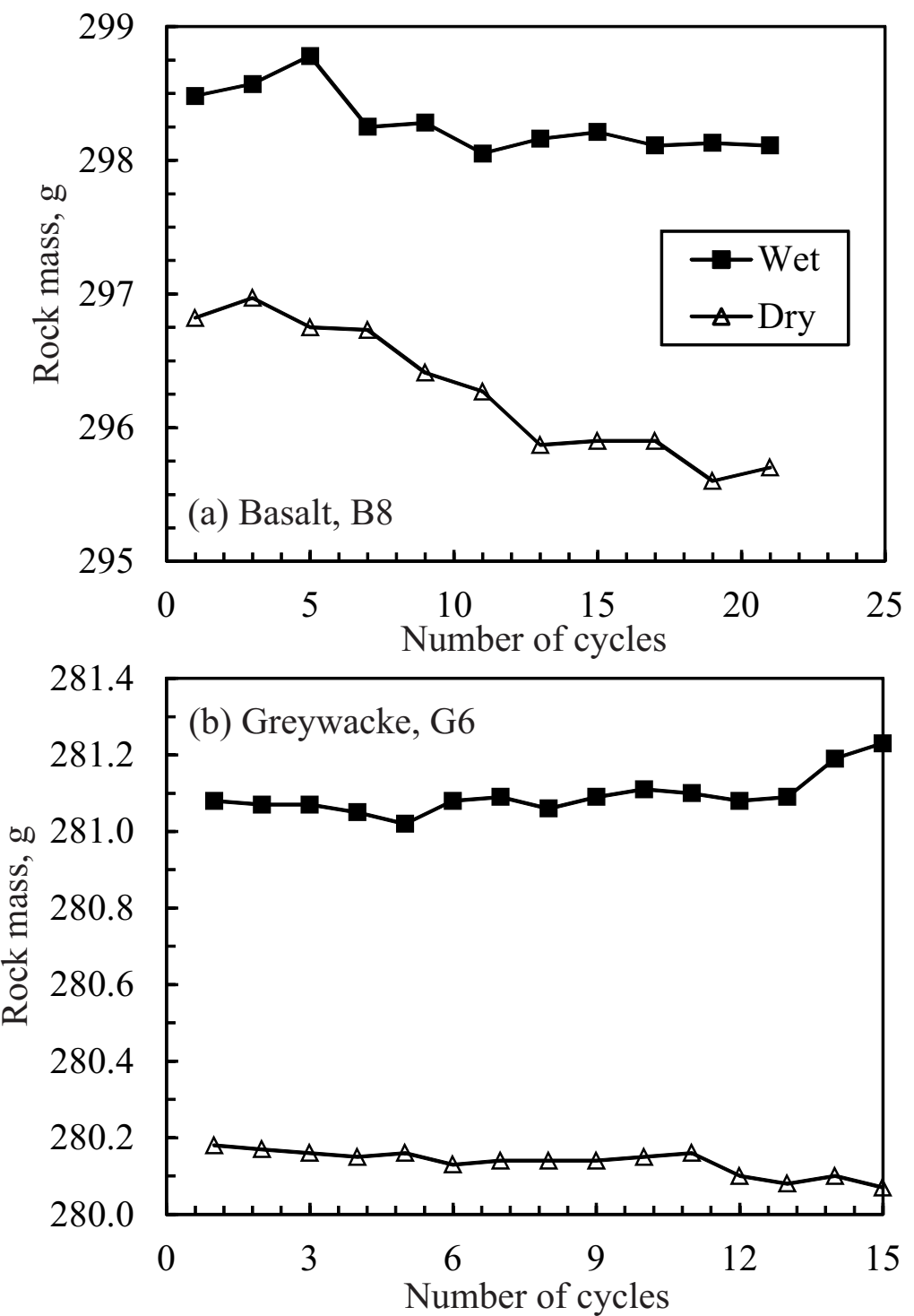


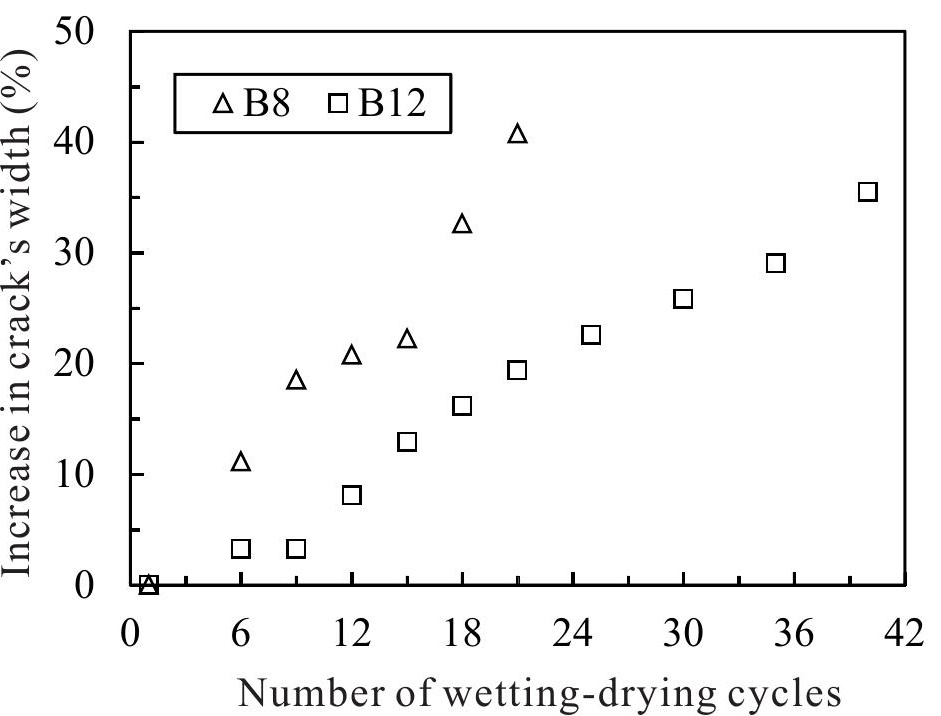



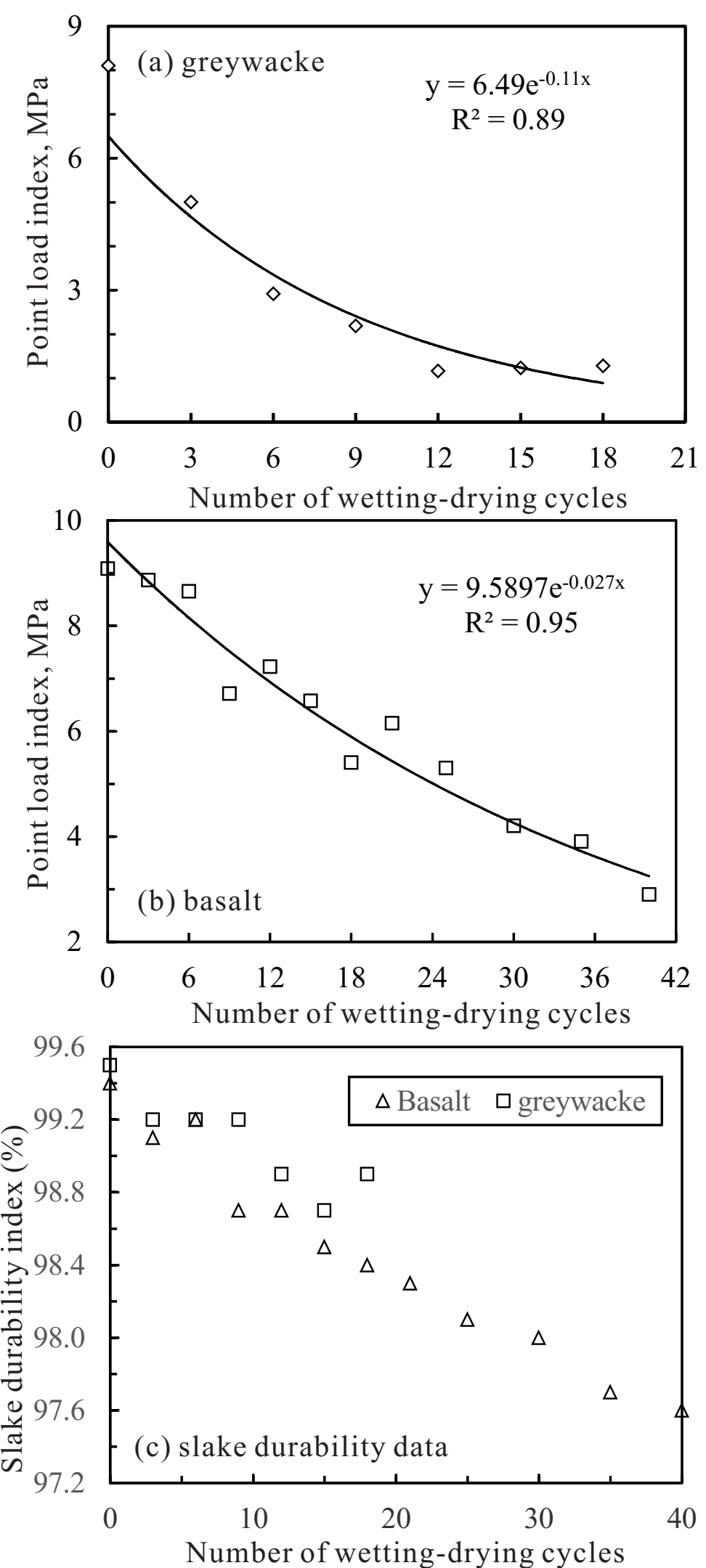


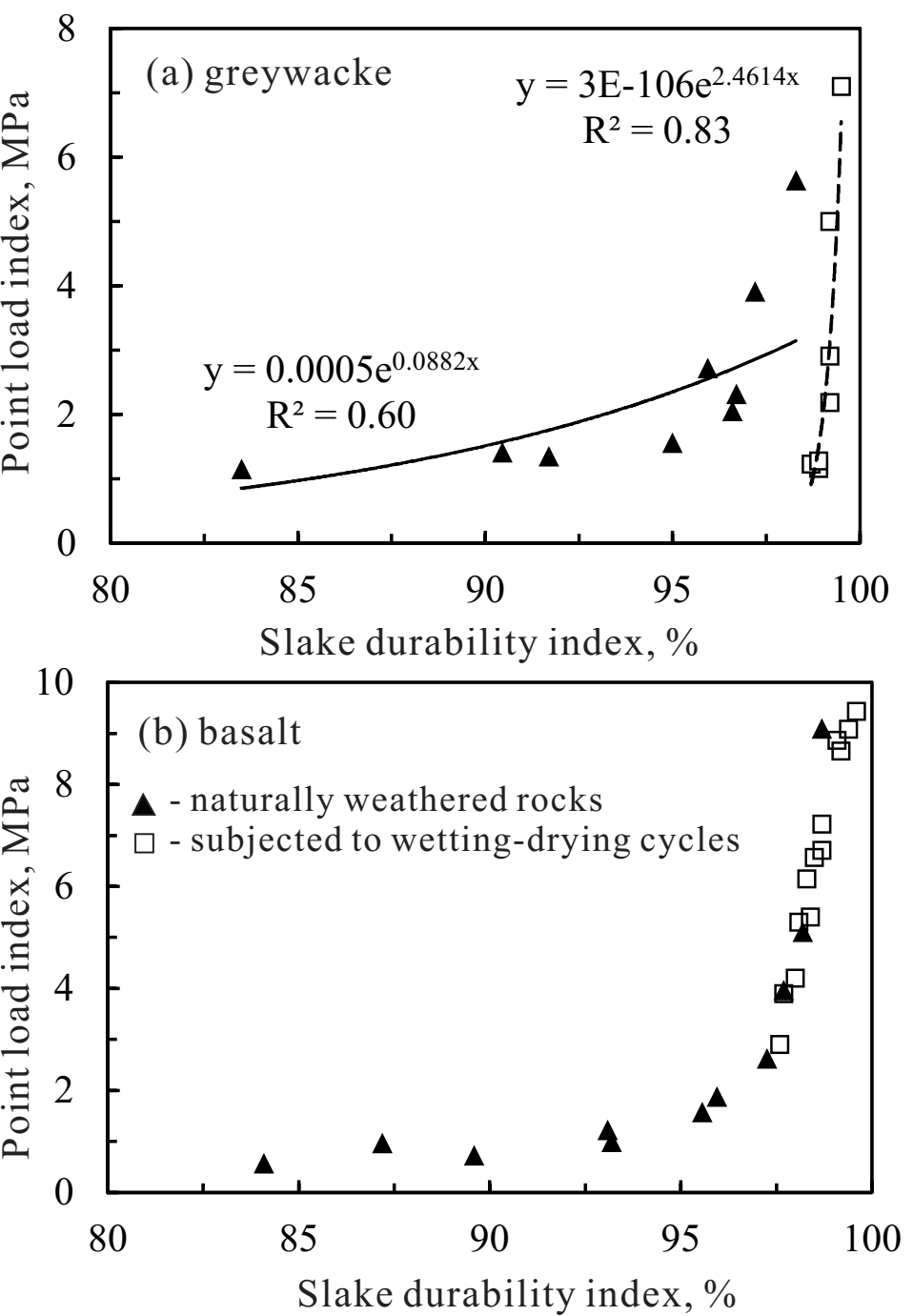



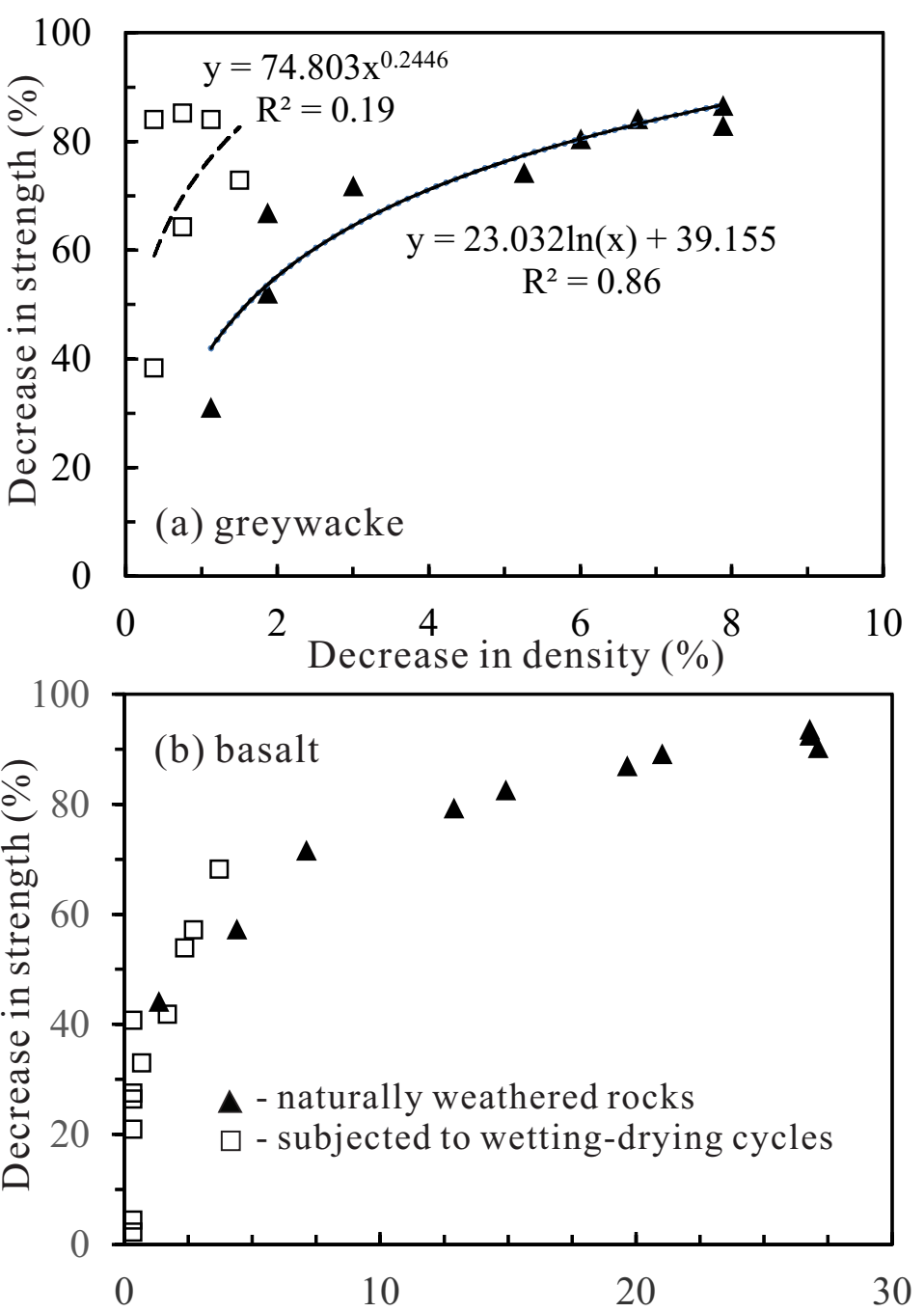

Decrease in density (\%) 